\section{EC Programmes Launched}

European Union research ministers meeting as the EU Research Council agreed on 1 December to the 10 remaining 4th Framework programmes, including Training and Mobility of Researchers. The programmes still need to be formally adopted by the Council of Ministers (European Council) on 15 December, but the European Commission expects to be able to launch calls for tender on this data (closing date: 15 March 1995) and thereafter at three-monthly intervals. If full calls cannot be published there will be advance notices which essentially represent the same thing. Industrial Materials and Technologies and Standards, Measurements and Testing have already been formally adopted (first calls for tender on 15 December). The Education Council has adopted SOCRATES (the ERASMUS follow on and including school-level education) but needs to agree with the European Parliament on the budget (it seeks 760 MECU instead of Parliament's $1006 \mathrm{MECU}$ ). Only Cooperation with Third Countries remains outstanding, although it is probable that an advance notice or a limited call covering some countries will be announced on 15 December. A standard application form will be used for all Framework programmes, differing only in the descriptions of individual programmes.

\section{FACHINFORMATIONSZENTRUM} KARLSRUHE

Gesellischoft für wissenschaftlich-technische Information mbH

\section{Database CONF of FIZ Karlsruhe available on STN}

The Database CONF contains about 104800 items on conferences in energy, physics, mathematics, and technology, space research, and chemistry, with more than 4000 records of future events, and is updated weekly.

Conference schedules are included as soon as they are received from scientific organizations worldwide.

An effective way to make use of the CONF file is to request a direct access via STN and/or establish a search profile which can be automatically processed to check the approximately 250 newly added data per week.

Please call or write to:

STN International, c/o FIZ Karlsruhe, Postfach 2466, D-76012 Karlsruhe \{Tel.:+49 (7247) 808 556; Fax:+49 (7247) 808666$\}$

\section{POST-DOCTORAL POSITIONS} SISSA/ISAS TRIESTE

The International School for Advanced Studies (SISSA/ISAS) in Trieste expects to offer a number of post-doctoral positions in the following fields: Mathematical Physics Theory of Condensed Matter - Theoretical Particle Physics - Theoretical Astrophysics and Cosmology - Cognitive Neuropsychology. These positions will be available from the autumn of 1995 for one year and renewable for a second year. Candidates, who must not be over 36 years of age, should submit their applications by 28 February 1995 with their curriculum vitae, list of published works and their research programme. They should arrange for 2 letters of reference to be sent by the same date.

Applications and correspondence should be sent to: Postdoc Programme, International School for Advanced Studies, Via Beirut, 2-4, I-34013 Trieste, Italy. Naturwissenschaftlichen Fakultät der Universität Wien ist die Planstelle eines/r

\section{Ordentlichen Universitätsprofessors/in für "Festkörperphysik mit} besonderer Berücksichtigung der Elektronischen Eigenschaften" ab Wintersemester 1995/96 wiederzubesetzen.

Der/Die Stelleninhaber/in muss das Fach Festkörperphysik in Forschung und Lehre vertreten und an den Lehraufgaben der physikalischen Institute (Anfängervorlesung) im üblichen Ausmass mitwirken. Erwünschter Forschungsbereich: Festkörperphysik mit Schwerpunkt Elektronische Eigenschaften (z.B. Transporteigenschaften, Spektroskopie, Photonik). Zusammenarbeit mit vorhandenen Arbeitsgruppen und Bereitschaft zur Leitung des Ludwig Boltzmann Institutes für Festkörperphysik in Wien werden erwarter: Bewerbungen mit den üblichen Unterlagen (Lebenlauf, Darstellung des wissenschaftlichen bzw. beruflichen Werdeganges, Schriftenverzeichnis mit Sonderdrucken von maximal fünf Publikationen, Darlegung der Lehrererfahrung und einer Uebersicht der laufenden und geplanten Forschungsvorhaben) sind bis 31. Januar 1995 an das Dekanat der Formal- und Naturwissenschaftlichen Fakultät der Universität Wien, A-1010 Wien, Dr. Karl-Lueger-Ring 1, zu richten.

\section{(3) \\ UNIVERSITY OF GENEVA}

The Faculty of Science has an opening of a position of

\section{Full Professor}

in

\section{THEORETICAL PHYSICS OF ELEMENTARY INTERACTIONS}

Responsibility: This is a full time appointment, comprising 6 hours of teaching per week and research in the area of theoretical physics of elementary interactions.

We are looking for candidates who master a wide range of modern theoretical subjects related to elementary interactions, and who have made significant contributions in these areas.

Degree requirements: Ph.D. or equivalent.

Starting date: 1 st October 1995, or as otherwise agreed.

Applications, including curriculum vitae and list of publications, are to be sent by January 31st, 1995 to the Dean of the Faculty of Science, 30, quai Ernest-Ansermet, $\mathrm{CH}-1211$ Geneva 4 (Switzerland), where further information concerning the job description and working conditions can be obtained.

NB: In an effort to involve both men and women in teaching and research, the University hopes to receive a greater number of applications from women.

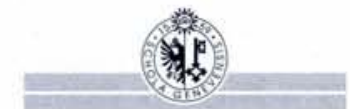 \\ UNIVERSITY OF GENEVA}

The Department of Physics of Condensed Matter announces an opening, beginning October 1st, 1995, for a position of

\section{FULL PROFESSOR or ASSOCIATE PROFESSOR}

in

\section{CONDENSED MATTER}

Teaching in French of introductory physics and condensed matter physics; research activity in the physics of metals or superconductors including studies at the mesoscopic and atomic scale.

The applicant should have a Ph.D. in Physics - or an equivalent degree - and experience in physics teaching and in leading a research group in condensed matter physics.

Letters of application, including a curriculum vitae and a list of publications, should be addressed before February 28th, 1995 to: Décanat de la Faculté des Sciences, 30 , quai Ernest-Ansermet, $\mathrm{CH}-1211$ Geneva 4, Switzerland, where additional information may be obtained.

NB: Qualified women are encouraged to apply. 